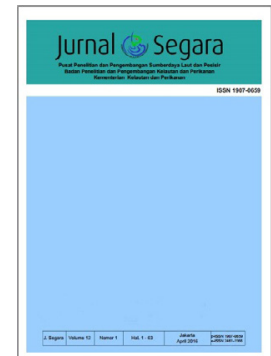

JURNAL SEGARA

http://ejournal-balitbang.kkp.go.id/index.php/segara

ISSN : 1907-0659

e-ISSN : 2461-1166

Nomor Akreditasi: 766/AU3/P2MI-LIPI/10/2016

\title{
KARAKTERISTIK OSEANOGRAFI FISIKA PERAIRAN ESTUARIA BENGKALIS BERDASARKAN DATA PENGUKURAN IN-SITU
}

\section{PHYSICAL OCEANOGRAPHIC CHARACTERISTICS OF BENGKALIS ESTUARINE WATERS BASED ON IN-SITU MEASUREMENT DATA}

\author{
Khairul Amri'1), Asep Priatna') \& Muchlizar'2) \\ 1)Peneliti pada Balai Riset Perikanan Laut, Jakarta \\ 2)Dinas Perikanan dan Kelautan Kabupaten Bengkalis
}

Diterima : 17 April 2017 ; Selesai Perbaikan : 20 November 2017 ; Disetujui Setelah Perbaikan: 30 Maret 2018

\begin{abstract}
ABSTRAK
Perairan estuaria Bengkalis memiliki peranan yang sangat strategis di tepi alur pelayaran internasional yang paling sibuk di dunia, yaitu Selat Malaka. Perairan ini merupakan daerah pertemuan antara massa air laut dari Selat Malaka dan massa air tawar dari muara Sungai Siak yang sangat khas dan menarik untuk dikaji. Penelitian mengenai karakteristik oseanografi fisika perairan ini dilakukan dalam periode 7 bulan selama tahun 2015. Metode yang digunakan adalah survei secara insitu menggunakan wahana kapal survei pada 16 stasiun pengukuran. Hasil yang diperoleh menunjukkan bahwa perairan estuaria Bengkalis merupakan perairan dangkal dengan kedalaman berkisar antara 6,1-37,3 m. Jenis-jenis substrat dasar perairan beragam, yaitu kombinasi komponen pasir $(2,7-86,69 \%)$, debu $(10,64-89,82 \%)$ dan liat $(2,66-13,30 \%)$. Pergerakan arus didominasi oleh arus pasut (arus pasang-surut) dengan kecepatan arus permukaan rata-rata berkisar 0,07-1,19 m/detik. Perairan ini tergolong keruh, dengan kisaran tingkat kecerahan rata-rata antara 0,42-0,95 m. Tingkat kecerahan cenderung menurun pada akhir tahun seiring masuknya musim penghujan. Rata-rata suhu perairan pada lapisan permukaan berkisar antara $29,74-30,94{ }^{\circ} \mathrm{C}$ dan di lapisan dasar berkisar antara $29,36-30,63^{\circ} \mathrm{C}$, dengan pola lebih dingin ke arah laut terbuka (Selat Malaka) dan lebih hangat ke arah muara Sungai Siak.
\end{abstract}

Kata kunci: Oseanografi fisika, perairan estuaria, Bengkalis, data in-situ.

\begin{abstract}
Bengkalis estuarine waters have played a strategic role at the edge of the one of the busiest international shipping lanes in the world, the Malacca Strait. This place is located where the oceanic water masses coming from the Malacca Strait were mixed with the fresh water mass from the Siak River mouth, which is make it an interesting to study. This research was conducted in a period of seven months during 2015, focussed on the physical oceanography aspects only. The method used was in-situ survey by using a research vessel at 16 measuring oceanographic stations. The results showed that Bengkalis estuarine waters is a shallow water with depths ranging from 6.1 to $37.3 \mathrm{~m}$. Types of substrates compotition, was various, ranging from sand (2.7 to $86.69 \%$ ), dust (10.64 to $89.82 \%$ ) and clay (from 2.66 to $13.30 \%$ ). Types of currents in the Bengkalis estuarine was dominated by tidal currents, with the surface current speed ranges from 0,07 to 1,19 m/sec. Bengkalis estuarine is turbid waters, with a range of transparant levels average between 0.42 to $0.95 \mathrm{~m}$. The transparant level tends to decrease at the end of the year as the entry of the rainy season. Sea surface temperature average ranging from 29.74 to $30.94{ }^{\circ} \mathrm{C}$ and in the bottom layer ranges from 29.36 to $30.63{ }^{\circ} \mathrm{C}$, with colder pattern found towards the open sea (Malacca Strait) while warmer towards Siak River mouth.
\end{abstract}

Keywords: Physical oceanography, estuarine waters, Bengkalis, in-situ data.

Corresponding author:

Jl. Pasir Putih I Ancol Timur, Jakarta Utara 14430. Email: kh amri@yahoo.com 


\section{PENDAHULUAN}

Perairan Bengkalis yang berada di Kabupaten Bengkalis, Provinsi Riau, memiliki letak yang sangat strategis yakni di tepi alur pelayaran internasional yang paling sibuk di dunia, yaitu Selat Malaka (Setiadi et al., 2015). Perairan Bengkalis terdiri dari dua bagian, yaitu perairan laut terbuka (open sea) di bagian timur dan utara Pulau Bengkalis, yang merupakan bagian dari Selat Malaka, serta perairan estuaria yang berada di bagian barat dan selatan Pulau Bengkalis.

Wilayah estuaria merupakan pesisir semi tertutup (semi-enclosed coastal) dengan badan air mempunyai hubungan bebas dengan laut terbuka, dimana kadar air laut terlarut dalam air tawar dari sungai (Bengen, 2002). Perairan estuaria Bengkalis terdiri dari perairan Selat Bengkalis yang memisahkan Pulau Bengkalis dengan Pulau Sumatera (Kabupaten Bengkalis); perairan Selat Padang yang memisahkan Pulau Sumatera (Sei Pakning, Kabupaten Bengkalis) dengan Pulau Padang (Kabupaten Kepulauan Meranti); dan perairan muara Sungai Siak (Kabupaten Siak) yang berada antara Selat Padang dan Selat Lalang (Kabupaten Kep. Meranti). Berdasarkan posisinya yang berada tepat di muara Sungai Siak tersebut, maka Pulau Bengkalis dikatakan juga sebagai delta Sungai Siak (Anonim, 2015).

Perairan Selat Bengkalis memiliki panjang sekitar 20 mil dengan lebar rata-rata 3,5 mil. Perairan ini terhubung langsung dengan perairan Selat Malaka di bagian utara dan timur laut, dipengaruhi oleh massa air laut terbuka dari Selat Malaka. Beberapa sungai kecil bermuara di Selat Bengkalis yakni di wilayah Kecamatan Bukit Batu dan Kecamatan Bengkalis (Ginting et al., 2015). Sementara perairan Selat Padang/Sei Pakning, lebih banyak mendapat pengaruh massa air tawar yang berasal dari limpasan muara Sungai Siak. Massa air yang berasal dari Sungai Siak ini cenderung keruh karena topografi sungai yang landai dengan substrat dasar liat dan berlumpur (Fajri et al., 2013). Selat Lalang yang memisahkan Pulau Padang dan Pulau Sumatera, selain mendapat pengaruh massa air muara Sungai Siak juga mendapat aliran massa air dari perluasan massa air muara Sungai Kampar di bagian barat Kabupaten Kepulauan Meranti.

Merta et al. (1999) menyatakan penurunan kualitas lingkungan diduga telah terjadi cukup lama di perairan estuaria Bengkalis, yang mempengaruhi kelangsungan hidup berbagai jenis sumberdaya ikan di perairan ini terutama mengancam jenis ikan terubuk (Suwarso et al., 2003). Oleh karena itu, pemahaman terhadap karakteristik parameter oseanografi fisika perairan estuaria Bengkalis ini, penting untuk diketahui lebih jauh.

Parameter oseanografi fisika yang umum diamati dan memegang peranan penting di suatu perairan di antaranya adalah tingkat kecerahan perairan, suhu perairan, bentuk dan material substrat dasar perairan, beserta pola arus yakni arah dan kecepatannya (Hutabarat, 1985). Untuk itu, tulisan ini mencoba menyajikan hasil penelitian terkait kondisi oseanografi fisika perairan estuaria Bengkalis berdasarkan data pengukuran in-situ sepanjang 2015 untuk memperkaya pemahaman karakteristik perairan ini.

\section{METODE PENELITIAN}

Penelitian dilakukan dengan survei secara in-situ pada 16 stasiun oseanografi di estuaria Bengkalis, Provinsi Riau (Gambar 1). Stasiun oseanografi berada di perairan Selat Bengkalis (Stasiun 1 s.d 7), Selat Padang/Sei Pakning (Stasiun 8 s.d 10), Selat Lalang (Stasiun 11 s.d 14), muara Sungai Siak (Stasiun 15) dan bagian hilir Sungai Siak yakni di Sungai Apit (Stasiun 16).
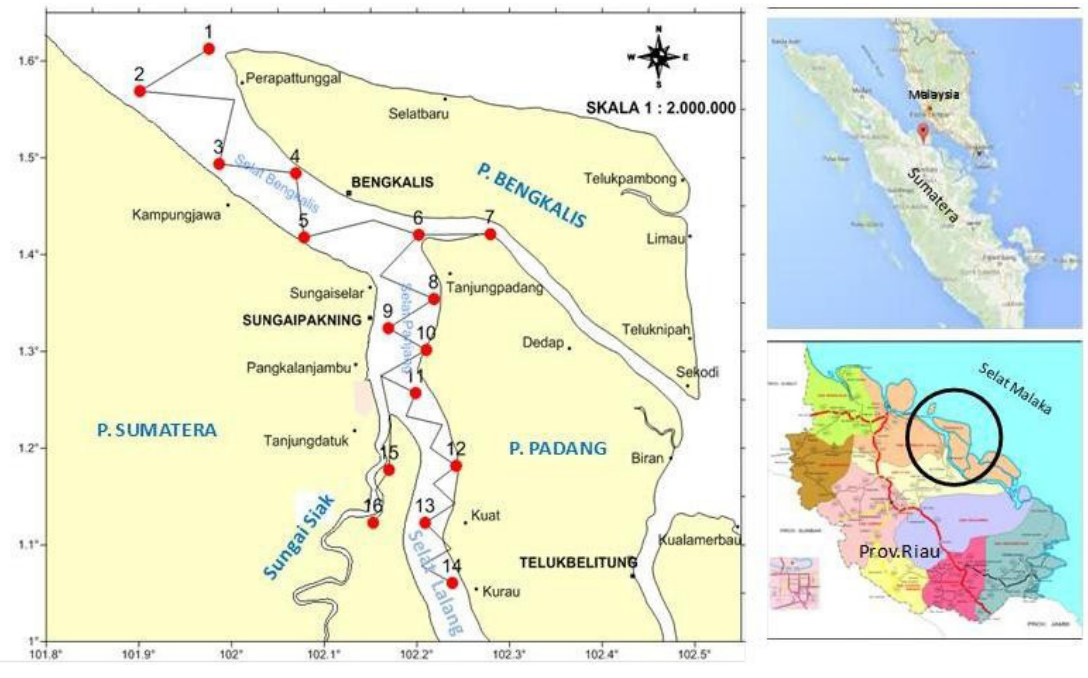

Gambar 1. Lokasi penelitian dan posisi stasiun oseanografi di estuaria Bengkalis. 
Selama 2015, dilakukan 7 kali survei yaitu pada 14-18 April; 19-24 Mei; 02-05 Juni; 11-16 Agustus; 0813 September; 27-31 Oktober; dan 16-23 November. Survei menggunakan wahana KM. Tenualosa berukuran 10 GT milik Dinas Kelautan dan Perikanan Kabupaten Bengkalis, berbahan fiber dengan mesin in-board.

Parameter oseanografi fisika yang diukur dan diamati terdiri dari kedalaman perairan, kecerahan perairan, jenis substrat, pola dan kecepatan arus permukaan serta suhu perairan. Data kedalaman perairan pada masing-masing stasiun diperoleh dari hasil pemeruman akustik scientific echosounder SIMRAD EY60 dengan frekuensi transducer $120 \mathrm{kHz}$. Kecerahan perairan diukur menggunakan piringan secchi disk arus diukur pada lapisan permukaan dengan floating drag dan parameter suhu diukur menggunakan termometer reverse pada lapisan dasar dan permukaan. Pengambilan air sampel pada lapisan dasar dan lapisan permukaan dilakukan menggunakan botol nansen. Ploting data dilakukan menggunakan software Surfer Ver.12.

\section{HASIL DAN PEMBAHASAN}

\section{Kedalaman Perairan}

Ekosistem estuaria Bengkalis, secara umum merupakan perairan dangkal karena masih bagian dari paparan benua dan sekitar 10\% mempunyai kedalaman di bawah 10 meter (Anonim, 2008). Kedalaman perairan berbeda antar lokasi pengukuran dengan rata-rata kedalaman $16 \mathrm{~m}$. Kedalaman perairan di Selat Bengkalis (Stasiun 1-7) berkisar antara 8,15$32,15 \mathrm{~m}$ (rata-rata $15 \mathrm{~m}$ ); di Selat Padang/Pakning (Stasiun 8-10) berkisar 12,140-18 m (rata-rata 14,8 m); di Selat Lalang (Stasiun 11-14) berkisar 14,50-37,30 $\mathrm{m}$ (rata-rata $22 \mathrm{~m}$ ) dan kedalaman perairan muara Sungai Siak (Stasiun 15) 9,7 m dan sekitar Sungai Apit (Stasiun 16) 6,10 m (Tabel 1).

Dari sebaran horizontal (Gambar 2) terlihat perairan yang terdalam di Selat Lalang posisinya di seberang Muara Sungai Siak (Stasiun 11) dengan kedalaman mencapai 37,30 $\mathrm{m}$ dan di Stasiun 3 di Selat Bengkalis yang posisinya berada di sisi timur Pulau Sumatera dengan kedalaman mencapai 32,15

Tabel 1.

Kedalaman Perairan pada lokasi sampling

\begin{tabular}{lllll}
\hline No Lokasi Perairan & \multirow{2}{*}{ No. Stasiun } & \multicolumn{2}{c}{ Kedalaman (m) } \\
\cline { 3 - 5 } & & Kisaran & Rata-rata \\
\hline 1 & Selat Bengkalis & 01 s.d 07 & $08,15-32,15$ & 15,0 \\
2 & Selat Padang/Sei Pakning & 08 s.d 10 & $12,14-18,00$ & 14,0 \\
3 & Selat Lalang & 11 s.d 14 & $14,5-37,3$ & 22,0 \\
4 & Muara Sungai Siak & 15 & 9,7 & 9,7 \\
5 & Sungai Apit & 16 & 6,1 & 6 \\
\hline
\end{tabular}

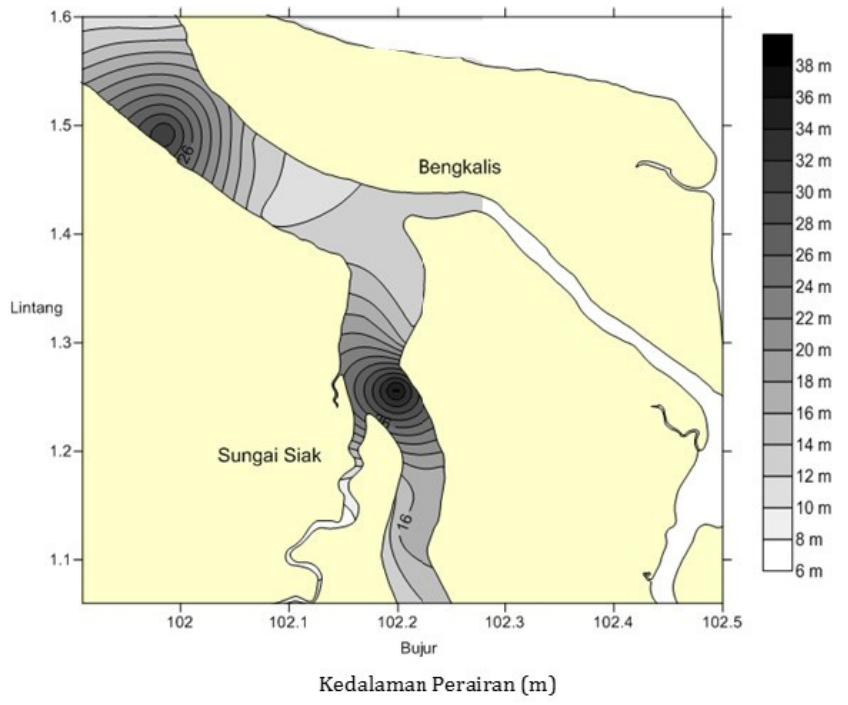

Gambar 2. Kedalaman perairan pada masing-masing stasiun sampling. 
Tabel 2.

Hasil Analisa Jenis-jenis Substrat di Perairan Bengkalis 2015

\begin{tabular}{llll}
\hline \multirow{2}{*}{ Parameter } & \multicolumn{3}{c}{ Komponen Jenis Substrat (\%) } \\
\cline { 2 - 4 } & Pasir & \multicolumn{1}{c}{ Debu } & Liat \\
\hline Kisaran & $2,70-86,69$ & $10,65-89,92$ & $2,66-12,37$ \\
Rata-rata & 17,86 & 72,98 & 9,16 \\
\hline
\end{tabular}

m. Kedalaman perairan di muara Sungai Siak (Stasiun 15) sekitar $9,7 \mathrm{~m}$ dan di bagian hilir Sungai Siak yaitu di Stasiun 16 yang berlokasi di Sungai Apit, merupakan perairan yang terdangkal dengan kedalaman masingmasing 6,1 m.

\section{Jenis Substrat}

Jenis-jenis substrat dasar perairan beragam, merupakan kombinasi komponen pasir, debu/lumpur dan liat (Tabel 2). Komposisi masing-masing jenis tersebutberbeda antar stasiun pengamatan. Komponen debu yang identik dengan lumpur ditemukan dalam prosentase besar di semua stasiun pengukuran ratarata $72,98 \%$, sementara pasir dan liat jumlahnya relatif lebih sedikit, masing-masing $18 \%$ dan $9 \%$. Komponen pasir lumpur ini sangat halus dan berwarna kecoklatan (Anonim, 2012).

Untuk perairan di lokasi Selat Bengkalis, substrat umumnya didominasi debu atau lumpur, dengan nilai berkisar antara $79,9 \%-89,8 \%$; sisanya pasir berkisar antara 2,4\%-12,2\%; dan liat berkisar antara $7,4 \%$ $11,6 \%$. Sementara perairan di sekitar Pakning/Selat Padang substratnya didominasi pasir berkisar antara $25,2 \%-53,3 \%$, yang terbesar prosentase pasirnya di Stasiun 8. Sementara di Selat Lalang, dominansi substrat pasir ditemukan di Stasiun 13. Muara dan bagian hilir Sungai Siak (Sungai Apit) dasarnya dominan debu (73\%) bercampur pasir (17\%) dan liat (10\%) (Gambar 3). Secara umum, perairan Bengkalis di seluruh bagiannya memang didominasi oleh substrat lumpur karena berada di muara sungai (Wedjatmiko, 2010).

\section{Tingkat Kecerahan Perairan}

Kecerahan perairan adalah suatu ukuran dalam rangka menentukan daya penetrasi cahaya matahari yang masuk ke perairan. Nilai kecerahan biasanya berbanding terbalik dengan nilai kekeruhan, semakin tinggi nilai kecerahan maka semakin dalam daya penetrasi cahaya masuk ke perairan, artinya air tersebut semakin jernih. Hal ini menyebabkan lapisan

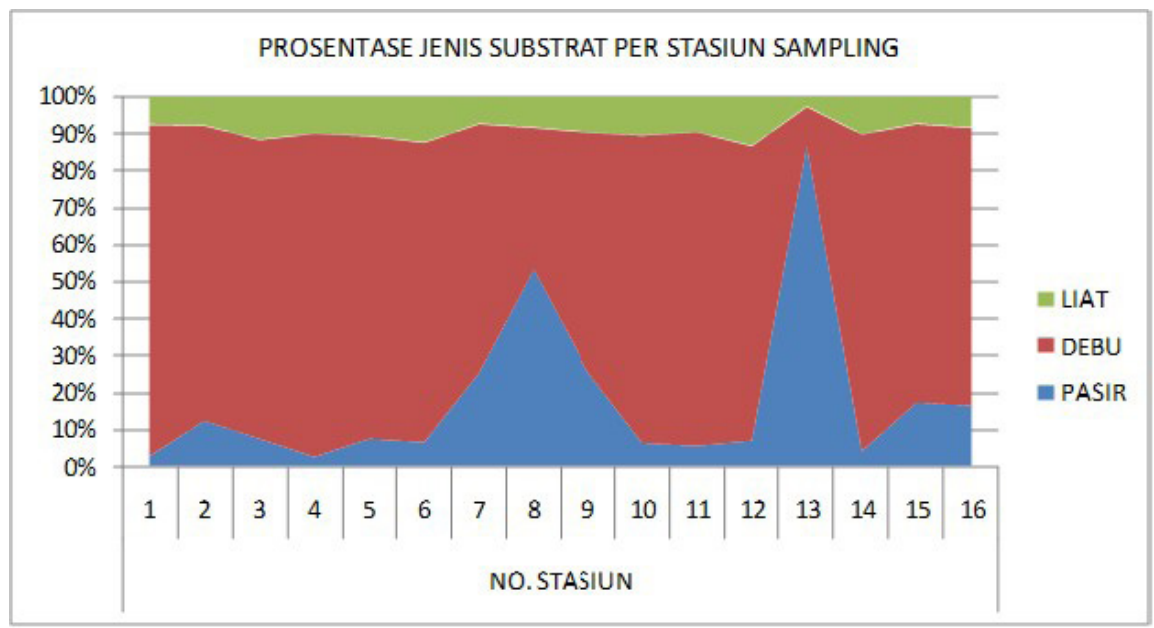

Gambar 3. Prosentase jenis-jenis substrat di perairan estuaria Bengkalis, 2015.

Tabel 3.

Kisaran dan rerata kecerahan perairan berdasarkan lokasi pengukuran, 2015

\begin{tabular}{llll}
\hline \multirow{2}{*}{ No } & \multirow{2}{*}{ Lokasi Perairan } & \multicolumn{2}{c}{ Kecerahan $(\mathbf{m})$} \\
\cline { 3 - 4 } & & Kisaran & Rerata \\
\hline 1 & Selat Bengkalis & $0,50-2.50$ & 0,95 \\
2 & Sel. Padang/Sei Pakning & $0,30-1.50$ & 0,70 \\
3 & Selat Lalang & $0,20-0.80$ & 0,55 \\
4 & Muara Sungai Siak & $0,40-1.00$ & 0,66 \\
5 & Sungai Apit & $0,10-1.00$ & 0,42 \\
\hline
\end{tabular}




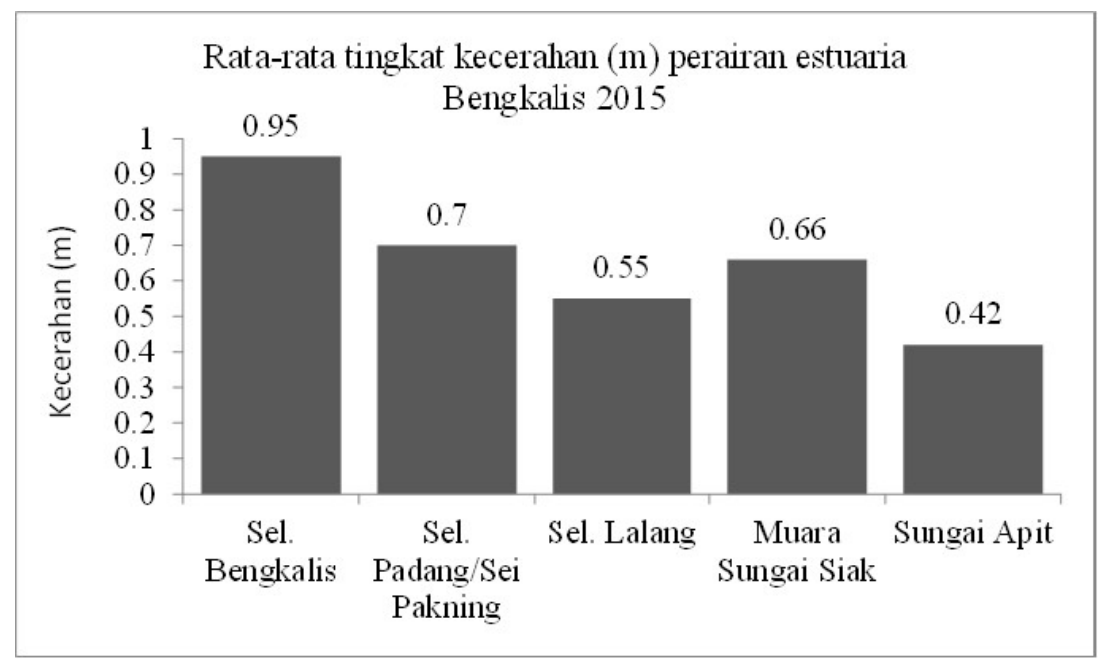

Gambar 4. Rata-rata kecerahan perairan di lokasi pengukuran, 2015.

produktif lebih tebal dan produktifitas primer perairan semakin tinggi.

Kecerahan perairan di masing-masing lokasi pengukuran pada tahun 2015 berbeda setiap bulan (Tabel 3). Tingkat kecerahan perairan yang paling tinggi adalah di Selat Bengkalis, berkisar antara $0,50-2,50 \mathrm{~m}$ (rata-rata $0,90 \mathrm{~m}$ ) dengan pola tingkat kecerahan semakin tinggi ke arah utara/timur laut (Selat Malaka). Angka ini lebih tinggi dibandingkan dengan hasil pengukuran tahun 2001, dimana tingkat kecerahan di lokasi ini hanya berkisar antara 0,45$1,55 \mathrm{~m}$ (Wagiyo, 2001). Perairan Selat Padang tingkat kecerahan berkisar antara 0,30-1,50 m (rata-rata $0,70 \mathrm{~m}$ ), sementara Selat Lalang tingkat kecerahan perairannya lebih rendah berkisar antara $0,20-0,80$ $\mathrm{m}$ (rata-rata 0,55 m); muara Sungai Siak berkisar antara 0,40-1,00 m (rata-rata 0,66 m) dan bagian hilir Sungai Siak (Sungai Apit) berkisar antara 0,10-1,0 m (rata-rata 0,42). Dapat dikatakan, perairan Sungai Apit, muara Sungai Siak dan Selat Lalang merupakan perairan yang paling keruh di estuaia Bengkalis, karena tingkat kecerahannya paling rendah (Gambar 4). Hasil pengukuran di lokasi yang sama pada tahun 2001, nilai kecerahannya jauh lebih rendah berkisar antara 0,34-0,38 m (Wagiyo, 2001).

Perubahan tingkat kecerahan perairan estuaria Bengkalis yang berbeda setiap bulannya, tergantung dominasi massa air terkait musim (Gambar 5). Pada bulan (April) yang identik dengan musim peralihan, tingkat kecerahan lebih tinggi, selanjutnya menurun pada pertengahan tahun (Juni), kemudian meningkat pada Juli-Agustus (musim timur) yang identik dengan musim kemarau dan selanjutnya mengalami penurunan yang signifikan sampai akhir tahun (musim barat), seiring masuknya musim hujan. Hal ini menunjukkan bahwa kekeruhan perairan di estuaria Bengkalis disebabkan oleh konsentrasi padatan tersuspensi yang masuk ke badan air. Merta (2001) menyatakan tingginya sedimentasi di perairan Bengkalis berasal dari aktivitas di daratan sepanjang aliran Sungai Siak menyebabkan tingginya tingkat kekeruhan di perairan.

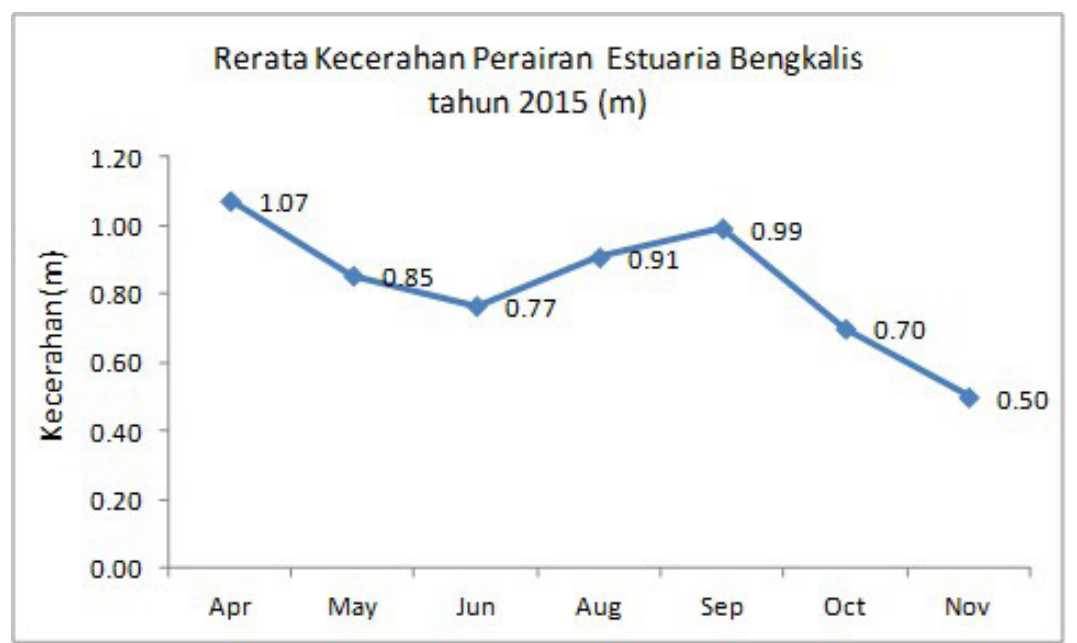

Gambar 5. Rerata kecerahan perairan estuaria Bengkalis, 2015. 


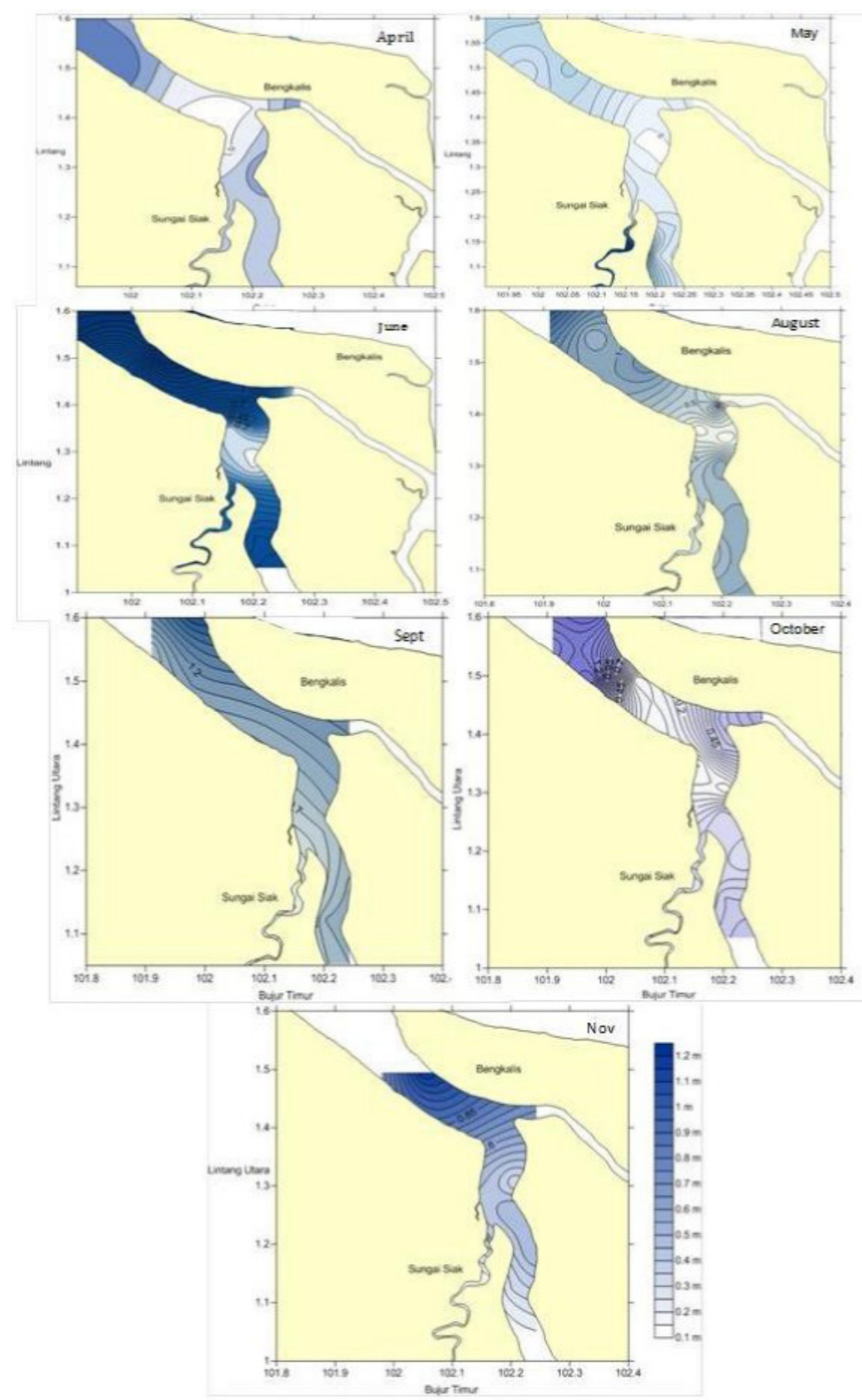

Gambar 6. Plot kecerahan perairan pada periode September, Oktober dan November.

Pola sebaran horizontal kecerahan perairan (Gambar 6) menunjukkan, perairan Selat Bengkalis di bagian utara dan timur laut yang berhubungan langsung dengan Selat Malaka, lebih tinggi tingkat kecerahannya, menandakan massa airnya lebih jernih. Hal ini sama dengan yang dilaporkan Merta (2001) bahwa Selat Bengkalis massa airnya lebih jernih dan menjadi habitat yang sesuai untuk kehidupan ikan terbuk. Perairan di sekitar muara Sungai Siak seperti di Sei Pakning/Selat Padang dan Selat Lalang, umumnya lebih keruh, hal ini dipengaruhi oleh aliran massa air yang berasal dari Sungai Siak yang cenderung keruh.

Dari pengamatan di lapangan, massa air yang berasal dari Sungai Siak tidak hanya lebih keruh akibat tingginya kadar suspensi terlarut, tetapi juga berwarna merah (seperti air teh) yang merupakan warna khas air gambut. Dari sebaran spasial ini terlihat bahwa sepanjang pengamatan (April-November) tingkat kekeruhan yang tertinggi di Sungai Apit dan muara Sungai Siak serta Selat Lalang.

\section{Arus Permukaan}

Secara umum sirkulasi arus permukaan di Perairan Bengkalis ke arah Selat Malaka (laut lepas) dipengaruhi oleh sistem sirkulasi arus permukaan di perairan Asia Tenggara yang masuk melalui Selat Malaka (Nedi et al., 2010). Dengan demikian, arus permukaan di kawasan ini tidak sepenuhnya mengikuti pola tiupan angin (Nedi et al., 2010). Sementara pergerakan arus di perairan estuaria dan selat (Selat 

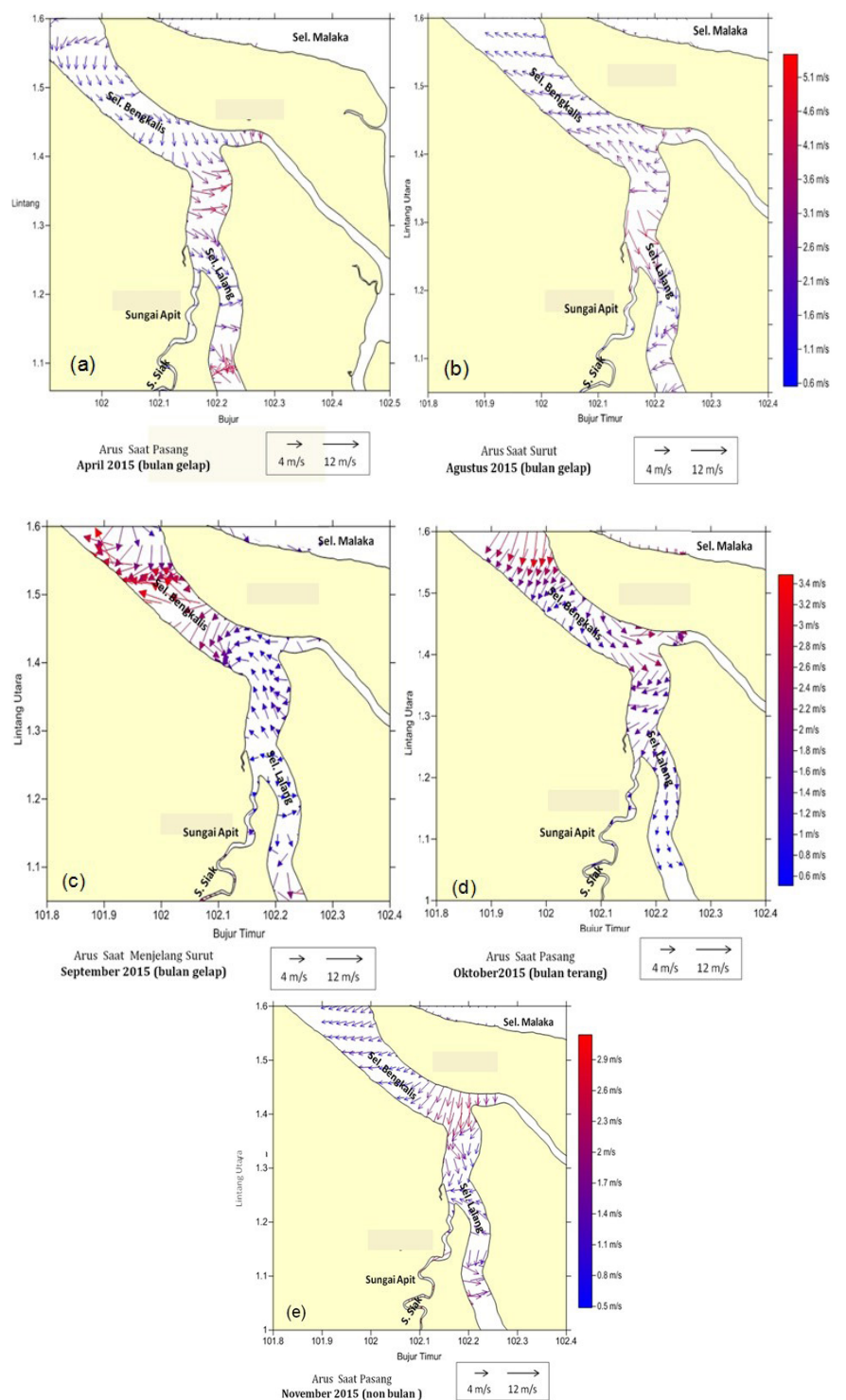

Gambar 7. Arus pasang surut pada lapisan permukaan di perairan estuaria Bengkalis 2015: (a) arus saat pasang pada bulan April; (b) arus saat surut pada bulan Agustus; (c) arus menjelang surut pada bulan September; (d) arus saat pasang bulan Oktober; dan (e) arus pasang bulan November .

Bengkalis, Selat Padang, dan Selat Lalang) didominasi oleh arus pasut (Anonim, 2008). Pada estuaria, arus pasut akan bergerak ke hulu pada saat air pasang dan keluar ke arah hilir pada saat surut. Tipe pasut di estuaria Bengkalis sebagai bagian dari Selat Malaka adalah tipe campuran dominasi harian ganda (Nontji, 2007).

Pada saat air pasang, arus akan merambat dari arah Utara menuju Selatan dan setelah itu arus akan berbelok ke arah Timur dan bergabung kembali dengan arus di Selat Malaka yang mengalir ke arah Tenggara dan sebagian masuk ke Selat Bengkalis (Gambar 7 a-d-e). Sebaliknya pada saat surut, arus akan bergerak dari arah Timur menuju Barat kemudian berbelok ke Utara dan ke luar di Selat Malaka (Gambar 7 b-c). Dorongan massa air pasang masuk ke Selat Bengkalis dari arah Selat Malaka di bagian Utara-Timur serta di bagian Selatan-Tenggara. Selain itu, dorongan massa air pasang juga berasal dari Selat Lalang. Massa air pasang tinggi akan mendesak massa air di muara Sungai Siak, sehingga air laut masuk cukup jauh di bagian hilir Sungai Siak yaitu sampai ke Sungai Apit.

Kecepatan pasut pada lapisan permukaan estuaria Bengkalis tahun 2015 berbeda antar lokasi dan waktu (bulan) pengukuran (Tabel 4). Secara umum, kecepatan arus berkisar 0,07-1,19 m/detik. Angka ini lebih tinggi dibandingkan hasil pengukuran 2014 yang berkisar 0,31 - 0,51 m/s (Agung, 2015), diduga karena perbedaan bulan atau waktu pengukuran.

Kecepatan arus pasut rata-rata di Selat Bengkalis berkisar $0,12 \mathrm{~m} /$ detik (November) - 0,60 $\mathrm{m} /$ detik (April); di Selat Padang/Pakning berkisar 0,13 $\mathrm{m} /$ detik (November) - 0,95 m/detik (April); di Selat 
Tabel 4.

Kisaran dan rerata kecerahan perairan berdasarkan lokasi pengukuran, 2015

\begin{tabular}{|c|c|c|c|c|c|c|}
\hline \multirow[t]{2}{*}{ Lokasi } & \multirow[t]{2}{*}{ Parameter } & \multicolumn{3}{|c|}{ Kecepatan Arus Pasut (m/detik) } & \multirow[b]{2}{*}{ Oktober } & \multirow[b]{2}{*}{$\overline{\text { November }}$} \\
\hline & & April & Agustus & September & & \\
\hline \multirow[t]{2}{*}{ Selat Bengkalis (Sta. 1 s.d 7) } & Kisaran & $0,40-1,01$ & $0,11-0,42$ & $0,13-0,43$ & $0,11-0.35$ & $0.05-0.15$ \\
\hline & Rerata & 0,60 & 0,20 & 0,29 & 0,18 & 0.12 \\
\hline \multirow[t]{2}{*}{ Selat Padang (Sta. 8 s.d 10) } & Kisaran & $0,64-1,19$ & $0,2-0,55$ & $0,16-0,21$ & $0,15-0.22$ & $0.04-0.21$ \\
\hline & Rerata & 0,95 & 0,35 & 0,17 & 0,17 & 0.13 \\
\hline \multirow[t]{2}{*}{ Selat Lalang (Sta. 11 s.d 14) } & Kisaran & $0,50-1,05$ & $0,12-0,34$ & $0,04-0,15$ & $0,05-0.11$ & $0.10-0.14$ \\
\hline & Rerata & 1,03 & 0,22 & 0,15 & 0,12 & 0.17 \\
\hline Muara Sungai Siak (Sta. 15) & Nilai & 0,49 & 0,35 & 0,11 & 0,11 & 0.12 \\
\hline Sungai Apit (Sta. 16) & Nilai & 0,40 & 0,05 & 0,20 & 0,14 & 0.32 \\
\hline
\end{tabular}

Lalang berkisar 0,12 m/detik (Oktober) - 1,03; m/detik (April); di Muara Sungai Siak berkisar 0,11 m/detik (September dan Oktober) - 0,49 (April); dan di Sungai Apit kecepatan arus rata-rata berkisar $0,05 \mathrm{~m} /$ detik (Agustus) - 0,40 m/detik (April).

Pada bulan April, di semua lokasi estuaria Bengkalis, kecepatan arus pasut cukup tinggi terutama di Selat Lalang dan Selat Padang (Gambar 8). Diduga pada bulan April arus pasang tertinggi terjadi bersamaan dengan masuknya aliran volume air yang cukup besar dari aliran massa air Sungai Siak ditambah dorongan perluasan massa air dari muara Sungai Kampar ke arah Selat Lalang. Pada bulan Agustus kecepatan arus pasut menurun, terkait puncak musim kemarau, ditandai melemahnya arus di bagian hilir ini Sungai Siak diduga akibat berkurangnya volume massa air sungai. Selanjutnya pada bulan November seiring masuknya musim hujan, terjadi peningkatan volume massa air Sungai Siak sehingga arus di bagian hilir diduga juga meningkat. Pada saat yang sama, kecepatan arus pasut di Selat Bengkalis dan Selat Padang melemah, diduga akibat berkurangnya dorongan arus dari Selat Malaka seiring perubahan arus musiman di perairan ini.

\section{Suhu Perairan}

Temperatur atau suhu permukaan perairan tropis umumnya hangat dan variasi tahunannya juga kecil, walaupun variasi harian yang tinggi sering terjadi. Suhu permukaan laut bulanan rata-rata Selat Malaka, tidak banyak bervariasi sepanjang tahun yakni sekitar $29^{\circ} \mathrm{C}$ (Wyrtki, 1961). Mubarak et al. (2016) menyebutkan suhu permukaan rata-rata perairan Selat Malaka $29,69^{\circ} \mathrm{C}$. Hal ini diperkirakan juga mempengaruhi dinamika sebaran suhu perairan estuaria Bengkalis pada umumnya.

Rata-rata suhu perairan estuaria Bengkalis pada lapisan permukaan berkisar antara $29,74-30,94^{\circ} \mathrm{C}$ sedikit lebih tinggi dibandingkan dengan suhu perairan Selat Malaka seperti yang disebutkan Wyrtky (1961). Mubarak et al. (2016) suhu terendah Selat Malaka ditemukan pada bulan Februari $\left(28,12^{\circ} \mathrm{C}\right)$ dan yang tertinggi pada bulan Mei $\left(30,81^{\circ} \mathrm{C}\right)$. Kisaran suhu

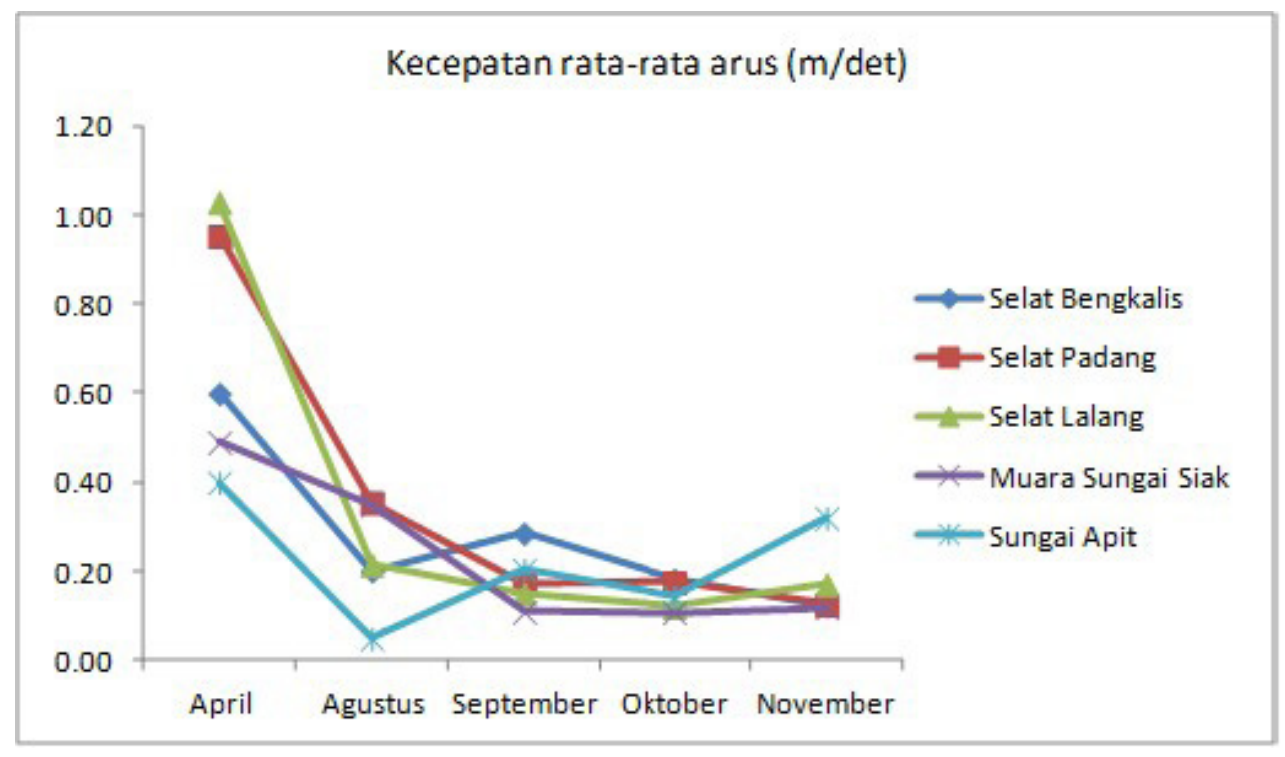

Gambar 8. Kecepatan rerata arus pasut permukaan perairan estuaria Bengkalis, 2015. 


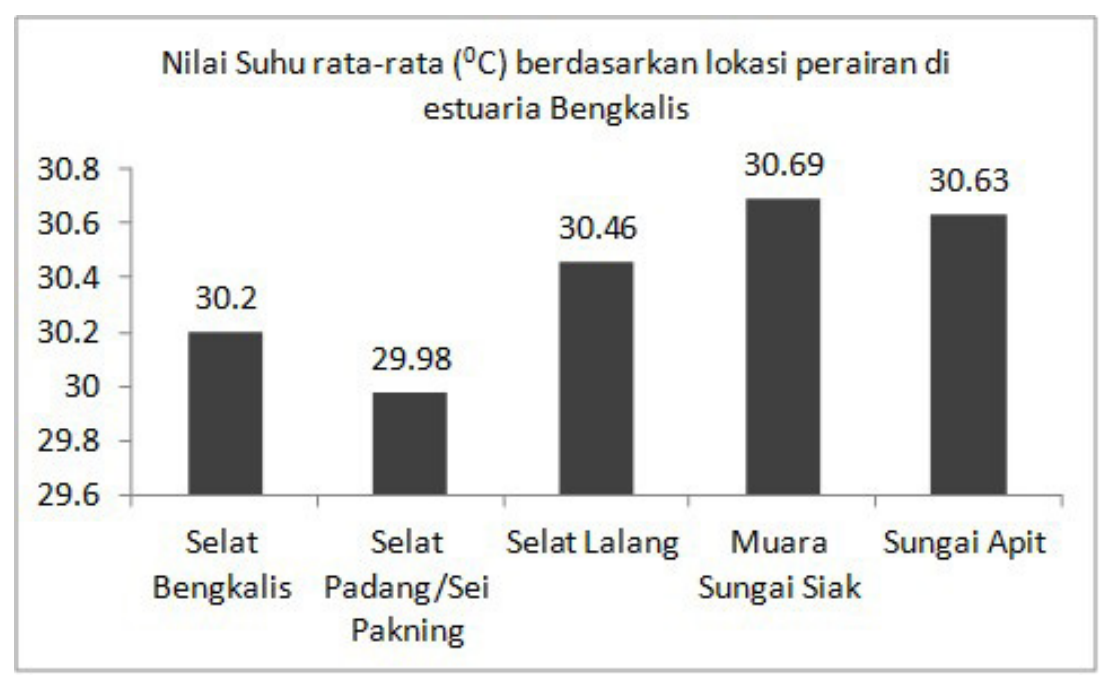

Gambar 9. Perbandingan nilai rata-rata suhu permukaan laut di estuaria Bengkalis, 2015.

lapisan permukaan pada tahun 2015 ini juga sedikit lebih tinggi dibandingkan dengan hasil pengukuran di Selat Bengkalis tahun 2001 yang berkisar antara 29,90-30,80 $\mathrm{C}$ (Wagiyo, 2001). Sementara suhu bulan September 2013 berkisar antara $28,7-30,33^{\circ} \mathrm{C}$ (Brown et al., 2014).

Tingginya suhu permukaan laut perairan estuaria Bengkalis disebabkan besarnya pengaruh wilayah pesisir terutama aliran massa air dari Sungai Siak. Disamping itu, juga karena kedalaman perairan yang lebih dangkal, sehingga pemanasan lebih intensif. Menurut Nontji (2007), faktor meteorologi berperan terhadap tinggi-rendahnya suhu perairan dipengaruhi curah hujan, penguapan, kelembaban udara, suhu udara, kecepatan angin dan intensi radiasi matahari. Hal lain yang menyebabkan tingginya suhu permukaan laut adalah, letak posisi geografis Bengkalis yang berada pada lintang rendah (khatulistiwa). Menurut Stewart (2003), penyebaran suhu secara horizontal pada permukaan laut membentuk zona berdasarkan letak lintang, semakin mendekati garis khatulistiwa (lintang rendah) suhu akan semakin meningkat.

Berdasarkan lokasi perairannya, sepanjang pengamatan tahun 2015, rata-rata suhu permukaan laut ke arah Selat Malaka (Selat Bengkalis dan Selat Padang) lebih dingin (Gambar 9), karena pengaruh aliran massa air dari Selat Malaka suhunya lebih dingin. Suhu permukaan laut yang lebih dingin di Selat Padang/Sei Pakning (Stasiun 8, 9 dan 10 pada Gambar 1), diduga pengaruh pengadukan massa air yang cukup intensif dengan lapisan dasar.

Sebaran secara horizontal suhu permukaan laut (SPL) estuaria Bengkalis selama pengamatan 2015 (Gambar 10) berkisar antara $29,74-30,94^{\circ} \mathrm{C}$. Suhu rata-rata terendah pada lapisan permukaan $\left(29,74^{\circ} \mathrm{C}\right)$ ditemukan pada bulan Oktober dan tertinggi $\left(30,94^{\circ} \mathrm{C}\right)$ pada bulan April. Dominasi massa air dengan suhu lebih dingin di lapisan permukaan terlihat pada Agustus-September-Oktober saat puncak musim timur, ketika aliran massa air dari Selat Malaka lebih dominan. Sementara pada awal tahun, massa air bersuhu lebih hangat tersebar lebih luas, karena perluasan massa air dari muara Sungai Siak dan muara Sungai Kampar (di Selat Lalang) yang memiliki karakter bersuhu lebih hangat. Secara umum, seperti dilaporkan Kasry et al. (2012) nilai sebaran suhu tersebut lebih tinggi dibandingkan dengan tahun 2008 yang berkisar 28,6 $-30,6^{\circ} \mathrm{C}$ dan pada tahun 2010 berkisar $28,1-29,0^{\circ} \mathrm{C}$. Jika mengacu kepada kondisi iklim, tahun 2015 merupakan tahun El Niño (Martono, 2016). Diduga, untuk perairan Selat Malaka dampaknya justru menyebabkan suhu permukaan laut sedikit lebih tinggi dibanding tahuntahun normal. Muhammad et al. (2012) menyebutkan pada saat El Niño, transpor massa air di bagian barat laut Selat Malaka pergerakannya melemah dan di bagian tenggara menguat dibandingkan pada kondisi tahun normal dan La Nina. Diduga, pada saat tersebut massa air yang berasal dari arah tenggara yang bersuhu lebih hangat mendominasi.

Pada lapisan dasar, pola sebaran spasial suhu relatif sama dengan lapisan permukaan (Gambar 11), namun nilai sebarannya sedikit lebih rendah dibandingkan dengan lapisan permukaan, yaitu berkisar antara $29,36-30,63^{\circ} \mathrm{C}$. Suhu rata-rata lapisan dasar tertinggi $\left(30,63^{\circ} \mathrm{C}\right)$ pada bulan Mei dan terendah $\left(29,36^{\circ} \mathrm{C}\right)$ bulan September.

Perbedaan nilai sebaran suhu rata-rata lapisan permukaan dan dasar di estuari Bengkalis, tidak terlalu besar berkisar antara $0,01-0,52^{\circ} \mathrm{C}$ (Tabel 5) dan grafik (Gambar 12). Perbedaan tertinggi antara suhu perairan lapisan permukaan dengan suhu lapisan dasar perairan pada bulan September $\left(0,52^{\circ} \mathrm{C}\right)$. Peningkatan suhu lapisan permukaan pada bulan 

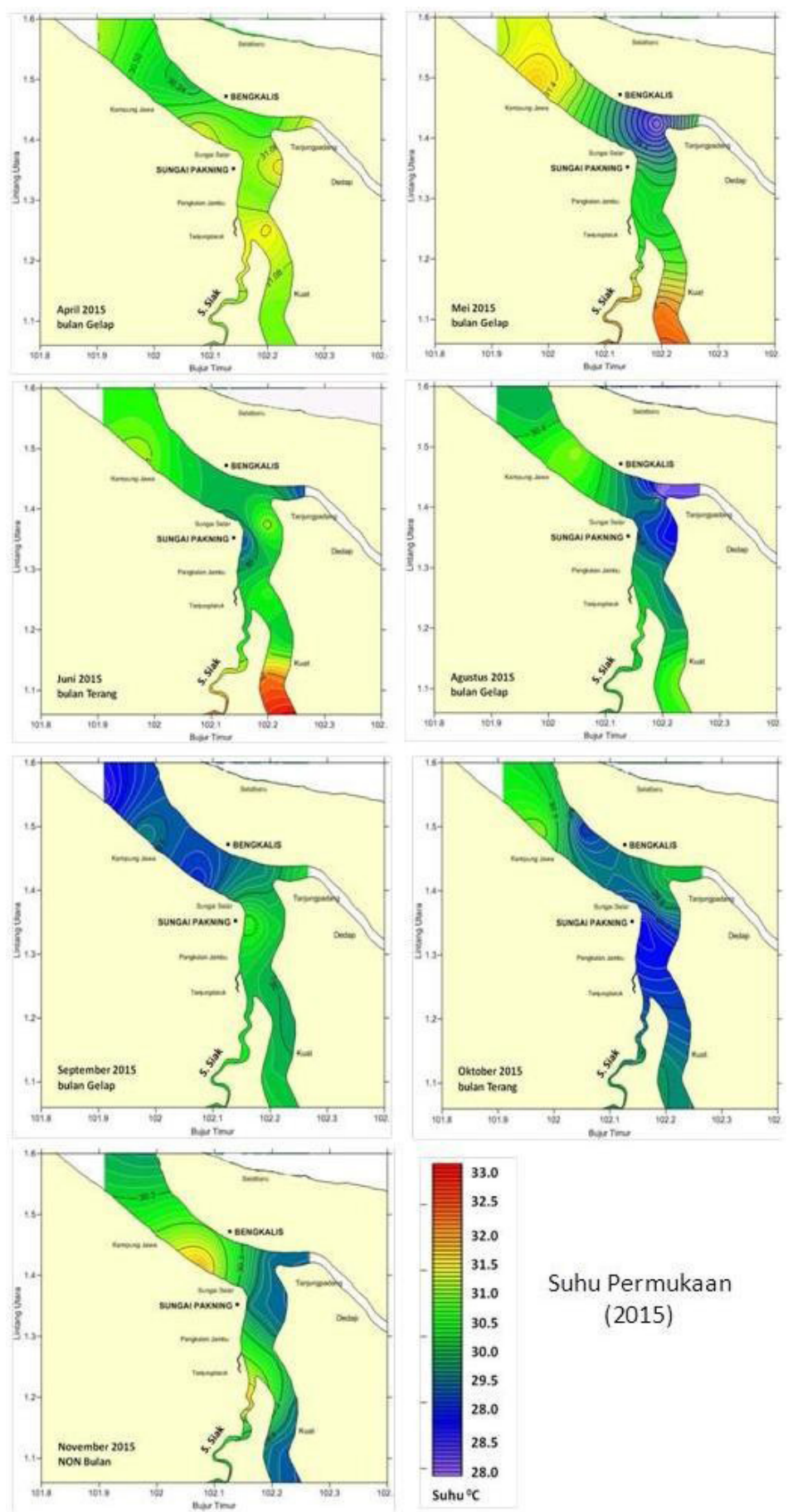

\section{Suhu Permukaan}

(2015)

Gambar 10. Pola sebaran suhu lapisan permukaan perairan estuaria Bengkalis pada 2015.

November, yang memiliki perbedaan nilai sebaran sekitar $0,49^{\circ} \mathrm{C}$ dari suhu pada lapisan dasar, diduga akibat mulai meningkatnya volume massa air bersuhu lebih hangat dari aliran Sungai Siak, seiring memasuki musim penghujan.

Dari nilai dan pola sebaran parameter oseanografi fisika, secara umum dapat dinyatakan bahwa sebagai perairan estuaria, perairan Bengkalis, merupakan daerah pertemuan antara massa air laut dan massa air tawar yang bersifat unik (Bengen, 2004). Wolanski (2007) menyebutkan, pencampuran kedua macam air tersebut menghasilkan sifat fisika lingkungan khusus yang tidak sama dengan sifat air sungai maupun sifat air laut. Berdasarkan pengaruh massa airnya, batasan estuaria ini dapat diperluas ke hulu sungai sampai batas pengaruh maksimum pasang surut. Karena topografinya yang datar, maka pengaruh pasang surut dapat mencapai jauh ke hulu, seperti yang terjadi pada Sungai Siak. Sebaliknya ke arah laut pengaruh air tawar dapat dirasakan hingga radius $5 \mathrm{~km}$ dari mulut sungai (Anonim, 2008).

Meskipun estuaria Bengkalis dikategorikan sebagai laut dangkal, namun terlihat adanya perbedaan nilai sebaran suhu rata-rata antara lapisan permukaan 
Tabel 5 .

Suhu rata-rata lapisan permukaan dan dasar perairan estuaria Bengkalis, 2015

\begin{tabular}{llllllll}
\hline Lapisan Perairan & \multicolumn{7}{c}{ Temperatur/Suhu $\left({ }^{\circ} \mathbf{C}\right)$} \\
\hline \multirow{3}{*}{ Permukaan } & Apr & Mei & Jun & Aug & Sep & Oct & Nov \\
Dasar & 30,94 & 30,76 & 30,69 & 29,89 & 29,88 & 29,74 & 30,13 \\
\hline
\end{tabular}
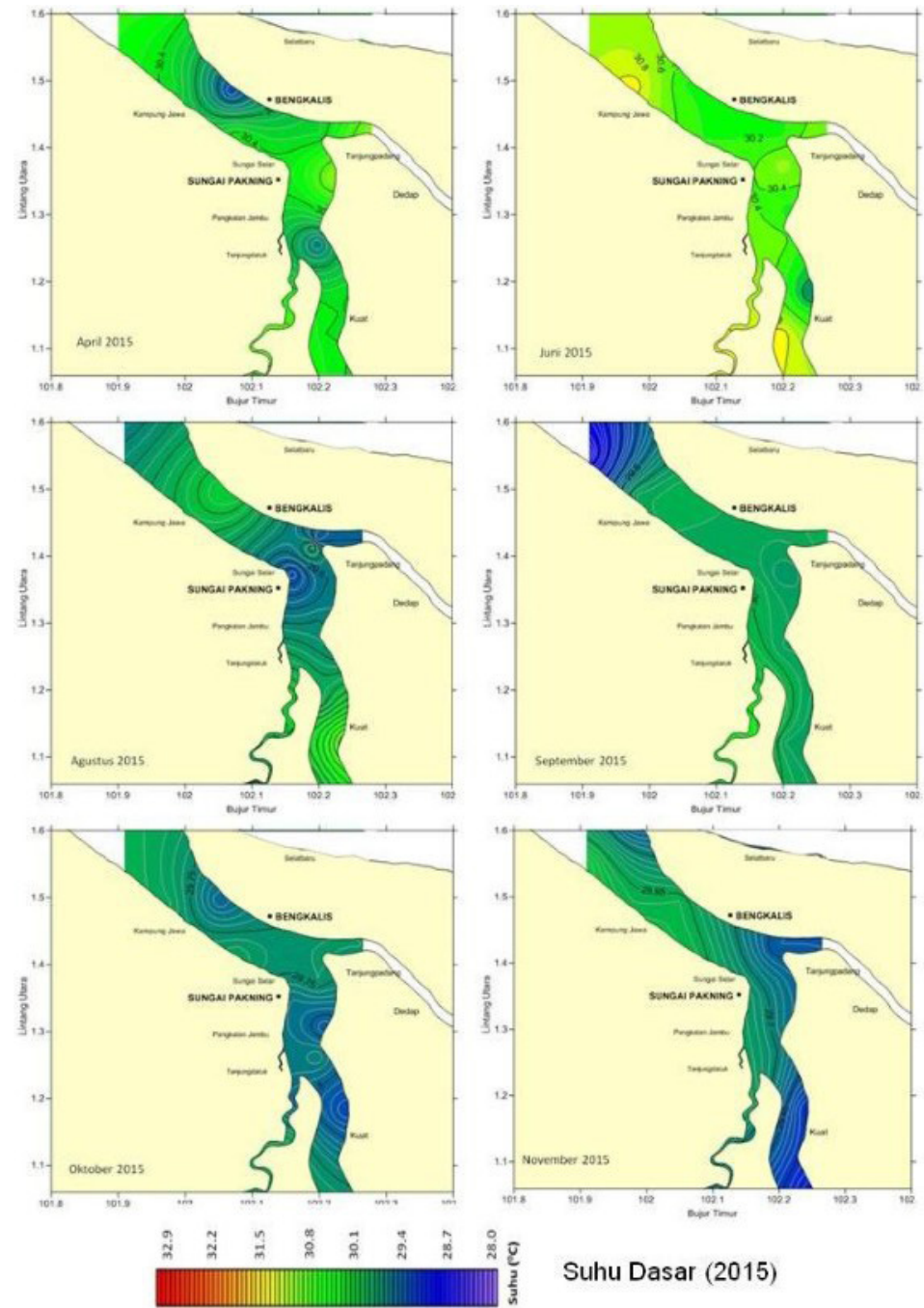

Gambar 11. Pola sebaran suhu lapisan dasar perairan estuaria Bengkalis pada 2015.

dan lapisan dasar, terkait dominansi jenis massa air. Perbedaan nilai sebaran suhu pada lapisan dasar yang lebih rendah dibandingkan dengan lapisan permukaan pada bulan September diduga lapisan air di dasar perairan didominasi oleh massa air oseanik dari Selat Malaka yang memiliki suhu lebih rendah. Sementara meningkatnya suhu perairan pada lapisan permukaan pada bulan November, diduga sebagai dampak dari masuknya massa air dengan suhu yang lebih hangat dari daratan melalui aliran massa air Sungai Siak, terkait dengan masuknya musim penghujan. Hal yang sama terlihat pada bulan April yang menunjukkan massa air estuaria Bengkalis pada awal tahun (sampai April) masih mendapat pengaruh yang besar dari massa air bersuhu lebih hangat dari daratan melalui aliran Sungai Siak pada penghujung musim hujan.

Pola sebaran suhu pada lapisan permukaan maupun lapisan dasar menunjukkan adanya perbedaan suhu per bulannya antara di Selat Bengkalis, Selat Padang, muara Sungai Siak dan Selat Lalang. Dari pola sebarannya terlihat bahwa pada bulan April-Mei-Juni, suhu permukaan cenderung tinggi. Sebaliknya, pada Agustus-September-OktoberNovember, suhu permukaan laut cenderung rendah Diduga pada Agustus-September-Oktober-November pengaruh massa air Selat Malaka (dengan suhu lebih dingin) lebih dominan di estuaria Bengkalis. Hal ini sesuai dengan temuan Masrikat (2002) bahwa pada musim timur suhu terendah perairan di bagian selatan 


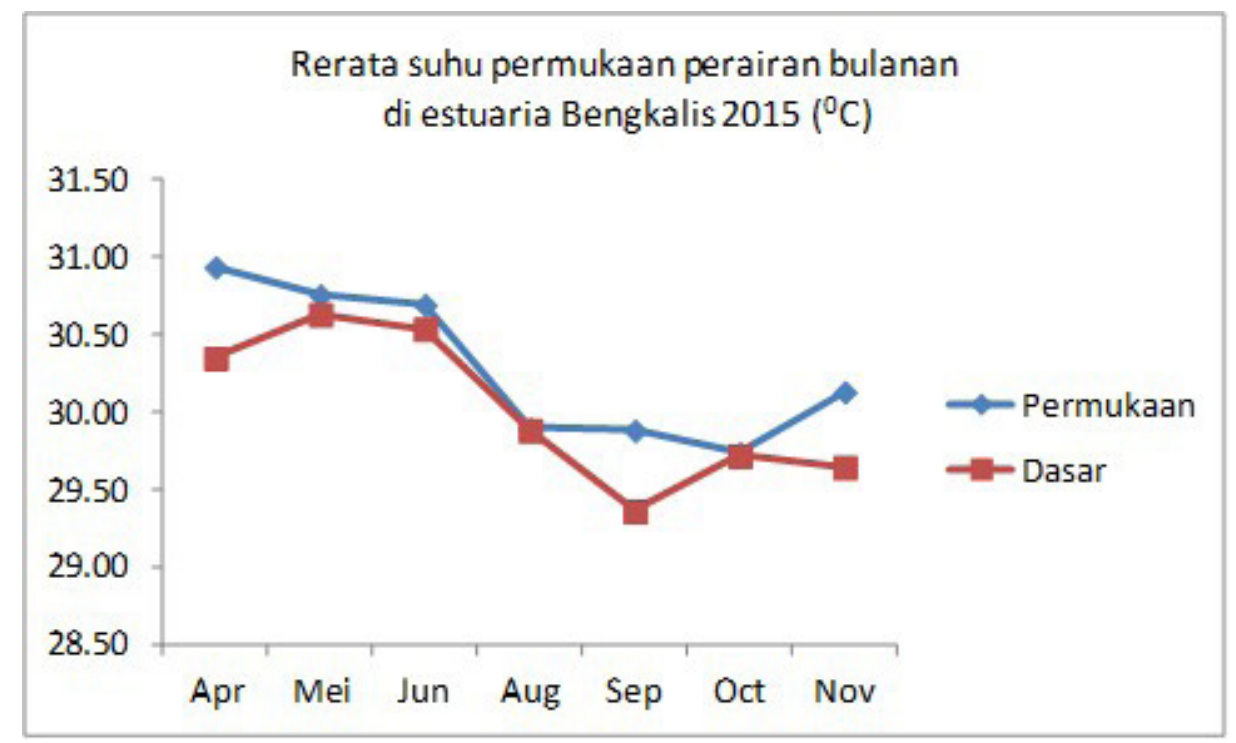

Gambar 12. Fluktuasi rerata suhu pada permukaan dan dasar perairan estuaria Bengkalis pada 2015.

Selat Malaka $29,97^{\circ} \mathrm{C}$. Sementara pada April-MeiJuni massa air tawar (yang bersuhu lebih hangat) mendominasi melalui dorongan limpasan massa air dari muara Sungai Siak. Pada periode yang sama, massa air hangat juga mendominasi perairan Selat Lalang, yang berasal dari massa air dari arah barat.

Jika dilihat dari pola sebarannya, massa air bersuhu hangat di Selat Lalang ini dipengaruhi oleh massa air limpasan muara Sungai Kampar yang bermuara di Kabupaten Kep. Meranti. Meskipun relatif jauh jaraknya, namun volumenya besar dan lebar muaranya sekitar $7 \mathrm{~km}$ (Anonim, 2008). Karena pergerakan arus (pasut), massa air tersebut terdorong masuk ke Selat Lalang.

Dari pola pengelompokkan massa air berdasarkan suhu, pada lapisan permukaan maupun dasar terlihat bahwa Selat Padang/Sei Pakning (Stasiun 8, 9 dan 10) merupakan lokasi pertemuan antara massa air muara sungai Siak dan massa air yang mendapat pengaruh massa air laut dari Selat Malaka. Menurut Kasry et al. (2012) massa air pencampuran ini masuk melalui Selat Bengkalis di bagian utara dan timur laut (massa air laut) dan massa air yang mendapat pengaruh dari massa air tawar, berasal dari limpasan massa air muara Sungai Siak dari arah barat.

Secara umum, agitasi laut yang kuat pada musim barat di Selat Bengkalis, menyebabkan peningkatan kekeruhan pada akhir tahun, yang berarti menurunkan tingkat kecerahan perairan. Kekeruhan juga disebabkan oleh muatan sedimen tersuspensi dari daratan yang masuk ke perairan melalui Sungai Siak terutama pada musim hujan dan pada daerah yang lahan di daratan terbuka akibat pembukaan lahan pertanian atau pemukiman yang terdapat di sepanjang aliran Sungai Siak. Selain itu, kondisi udara Riau yang pada Agustus-September-Oktober 2015 diselimuti asap kebakaran hutan akibat EI Nino moderat (www. bbc.com), ikut mempengaruhi penetrasi sinar matahari, sehingga mempengaruhi tingkat kecerahan perairan pada saat itu.

Satu hal yang menarik, meskipun pada waktuwaktu tertentu pergerakan arus cukup kuat di Selat Padang, namun karena substrat dasarnya dominan pasir, menjadikan perairan ini relatif jernih. Sehingga sangat mendukung sebagai lokasi yang selama ini diduga sebagai lokasi pemijahan (spawning ground) ikan terubuk (Efizon et al., 2012), sekaligus merupakan salah satu lokasi penangkapan ikan (fishing ground) yang potensial.

\section{KESIMPULAN}

Dari penelitian ini dapat disimpulkan bahwa perairan estuaria Bengkalis merupakan perairan dangkal dengan kedalaman berkisar 6,1-37,3m karena masih merupakan bagian dari paparan benua dan sangat dipengaruhi oleh massa air dengan salinitas lebih tinggi dari Selat Malaka dan massa air muara dari Sungai Siak dan juga Sungai Kampar melalui perluasan massa air Selat Lalang. Massa air Selat Padang dan Selat Bengkalis yang berhubungan langsung dengan Selat Malaka memiliki suhu rata-rata yang lebih dingin $29,98^{\circ} \mathrm{C}$ (Selat Padang) dan $30,2^{\circ} \mathrm{C}$ (Selat Bengkalis), sebaliknya massa air yang mendapat pengaruh air tawar dari muara Sungai Siak di bagian barat dan selatan (Selat Lalang) memiliki suhu yang cenderung hangat $\left(29.57-31.87^{\circ} \mathrm{C}\right.$, rata-rata $\left.30,61^{\circ} \mathrm{C}\right)$ karena pengaruh pemanasan daratan yang masuk melalui limpasan massa air muara sungai. Substrat dasar perairan dominan disusun oleh material debu, sehingga dasar perairan dominan berlumpur, menjadikan perairan ini keruh dengan tingkat kecerahan yang rendah $(<1 \mathrm{~m})$. 
Peningkatan kekeruhan yang signifikan terjadi pada akhir tahun yang identik dengan musim penghujan.

\section{PERSANTUNAN}

Penelitian ini dibiayai APBD Pemerintah Kabupaten Bengkalis (Dinas Kelautan dan Perikanan) TA 2015. Pelaksanaan kegiatan dilakukan dalam kerangka Kerjasama Penelitian antara Dinas Perikanan dan Kelautan Kabupaten Bengkalis dengan Pusat Penelitian dan Pengembangan Perikanan, Badan Litbang Kelautan dan Perikanan, KKP. Penulis mengucapkan terima kasih atas bantuan dan kerjasama segenap tim yang terlibat.

\section{DAFTAR PUSTAKA}

Anonim, (2012). Direktori Pulau-Pulau Kecil Indonesia. Direktorat Pendayagunaan Pulau-Pulau Kecil. Ditjen Kelautan, Pesisir dan Pulau-Pulau Kecil. Kementerian Kelautan dan Perikanan. Jakarta.

Anonim, (2008). Laporan Akhir Kegiatan Identifikasi Potensi Sumberdaya Perikanan dan Kelautan Kabupaten Bengkalis. Dinas Perikanan dan Kelautan Kabupaten Bengkalis. 247 hal.

Anonim, (2015). Profil Kabupaten Bengkalis. Artikel online dalam https://id.wikipedia.org/wiki/ Kabupaten_Bengkalis.

Agung, A.F. (2014). Aplikasi Sistem Informasi Geografis Dalam Penentuan Daerah Pengoperasian Alat Tangkap Gombang di Perairan Selat Bengkalis Kecamatan Bengkalis Kabupaten Bengkalis Propinsi Riau. https://Fadilapresia.Blogspot. Co.Id/2016/12/Aplikasi-Sistem-InformasiGeografis.Html.

Bengen, D.G. (2002). Ekosistem dan sumber daya pesisir dan laut serta pengelolaan terpadu dan berkelanjutan. Makalah Prosiding Pelatihan Pengelolaan Wilayah Pesisir Terpadu.PKSSPLIPB. Bogor.

Brown, A. \& Pareng Rengi. (2014). Pelagic Fish Stock Estimation by Using the Hydroacoustic Method in Bengkalis Regency Waters. Jurnal berkala Perikanan Terubuk, Februari 2014 Vol. 42. No.1, hlm 21 - 34 .

Efizon, D., Djunaedi, O.S., Dhahiyat, Y. \& Koswara, B. (2012). Kelimpahan Populasi dan Tingkat Eksploitasi Ikan Terubuk (Tenualosa Macrura) di Perairan Bengkalis, Riau. Jurnal berkala Perikanan Terubuk, Februari 2012, hlm 52 - 65 Vol. 40. No.1.
Fajri, N.E. \& Kasry, A. (2013). Kualitas Perairan Muara Sungai Siak ditinjau dari Sifat Fisik-Kimia dan Makrozoobentos. Jurnal Berkala Perikanan Terubuk, Vol. 41. No.1.Februari 2013, hal 37- 52.

Ginting, R.S., Elvira, R. \& Yusfiati. (2015). Inventarisasi Jenis-jenis Ikan Buntal (Famili Tetraodontidae) di Muara Perairan Bengkalis, Kabupaten Bengkalis, Provinsi Riau. Jurnal JOM FMIPA Vol. 2 No. 1 Februari 2015.

Hutabarat, S. (1985). Pengantar Oceanografi. UI Press: Jakarta.

Kasry, A. \& Fajri, N.E. (2012). Kualitas Perairan Muara Sungai Siak Ditinjau dari Parameter FisikKimia dan Organisme Plankton. Jurnal berkala Perikanan Terubuk, Juli 2012, Vol. 40 No.2. p:96 -113 .

Martono. (2016). Dampak El Niño 1997 dan El Niño 2015 terhadap Konsentrasi Klorofil-A di Perairan Selatan Jawa dan Bali-Sumbawa. Majalah IImiah Globë Volume 18 No.1 April 2016: P 01 - 08.

Masrikat, J.A.N. (2002). Karakteristik Oseanografi Fisik dan Distribusi Ikan di Perairan Laut Cina Selatan dan Selat Malaka pada Musim Timur. Tesis. Program Pascasarjana Institut Pertanian Bogor (tidak dipublikasikan).

Merta, G.S., Suwarso., Wasilun., Wagiyo, K., Girsang, E.S. \& Suprapto. (1999). Status populasi dan bio-ekologi ikan terubuk Tenualosa macrura (Clupeidae) di Propinsi Riau. Jurnal Penelitian Perikanan Indonesia Vol. V.No.3 .p 15-29.

Merta, G.S. (2001). A description of the Terubuk fishery (Tenualosa macrura) in the Bengkalis Region of Riau Province, Indonesia. Proceeding of the International Terubok Conference, Serawak Malaysia. p 85-90.

Mubarak., Nurhuda, A. \& Ghalib, M. (2016). Analisis Suhu Permukaan Laut Selat Malaka. Prosiding Seminar Nasional Pelestarian Lingkungan dan Mitigasi Bencana. Pekanbaru 28 Mei 2016. ISBN 978-979-792-675-5. Hal. 619-626.

Muhammad., Rizal, S. \& Affan, J.M. (2012). Pengaruh ENSO (EI Niño and Southern Oscillation) terhadap transpor massa air laut di Selat Malaka. Jurnal Depik Vo.1, No.1. April 2012. p 61-67.

Nedi, S., Pramudya, B., Riani, E., \& Manuwoto. (2010). Karakteristik Lingkungan Perairan Selat Rupat. Jurnal Ilmu Lingkungan. Vol. 1. No.4. ISBN 1978.5283. Program Studi IImu Lingkungan PPS Universitas Riau. 
Nontji A. (2007). Laut Nusantara. Edisi Revisi. Jakarta. Penerbit Djambatan.

Setiadi, D., Arthur Brown \& Bustari. (2015). Distribution Target Strength In Waters Bengkalis Demersal Fish Province Riau. Jurnal online: http://jom. unri.ac.id/index.php/JOMFAPERIKA/article/ view/6238/5938.

Stewart, R.H. (2003). Introduction to Physical Oceanography. Departement of Oceanography Texas A\&M University.

Suwarso \& Merta, I.G. (2003). Penurunan Populasi dan Alternatif Pengelolaan Ikan Terubuk, Tenualosa macrura (Clupeidae), di Propinsi Riau. Jurnal Penelitian Perikanan Indonesia Vol. VI.No.2 .p; 25-36.

Wagiyo, K. (2001). Spawning sites and larval distribution of Terubuk (Tenualosa macrura) in the Bengkalis Region of Riau Province, Indonesia. Proceeding of the International Terubok Conference, Serawak Malaysia. p 168-178.

Wolanski, E. (2007). Estuarine Ecohydrology. Elsevier. Amsterdam. First Edition. 168p.

Wyrtki, K. (1961). The Physical Oceanography of South East Asian Waters. Naga Report Vol. 2. University California Press. La Jolla. CA.

Referensi internet:

(http://www.bbc.com/indonesia/berita indonesia/2016/03/160309_indonesia_riau_kebakaranhutan) 